\title{
Basic science (January 2007)
}

1. Belous AR, Hachey DL, Dawling S, Roodi N, Parl FF. Cytochrome P4501B1-mediated estrogen metabolism results in estrogen-deoxyribonucleoside adduct formation. Cancer Res 2007; 67: 812-817.

2. Bhati R, Gokmen-Polar Y, Sledge GW, Fan C, Nakshatri $\mathrm{H}$, Ketelsen D, Borchers $\mathrm{CH}$, Dial MJ, Patterson C, Klauber-DeMore N. 2-methoxyestradiol inhibits the anaphase-promoting complex and protein translation in human breast cancer cells. Cancer Res 2007; 67: 702-708.

3. Bosco EE, Wang Y, Xu H, Zilfou JT, Knudsen KE, Aronow BJ, Lowe SW, Knudsen ES. The retinoblastoma tumor suppressor modifies the therapeutic response of breast cancer. $J$ Clin Invest 2007; 117: 218-228.

4. Buchholz S, Schally AV, Engel JB, Hohla F, Heinrich E, Koester F, Varga JL, Halmos G. Potentiation of mammary cancer inhibition by combination of antagonists of growth hormonereleasing hormone with docetaxel. Proc Natl Acad Sci USA 2007; 104: 1943-1946.

5. Chang MY, Boulden J, Sutanto-Ward E, Duhadaway JB, Soler AP, Muller AJ, Prendergast GC. Bin1 ablation in mammary gland delays tissue remodeling and drives cancer progression. Cancer Res 2007; 67: 100-107.

6. Climent J, Dimitrow P, Fridlyand J, Palacios J, Siebert R, Albertson DG, Gray JW, Pinkel D, Lluch A, Martinez-Climent JA. Deletion of chromosome 11q predicts response to anthracyclinebased chemotherapy in early breast cancer. Cancer Res 2007; 67: 818-826.

7. Donato LJ, Suh JH, Noy N. Suppression of mammary carcinoma cell growth by retinoic acid: the cell cycle control gene Btg2 is a direct target for retinoic acid receptor signaling. Cancer Res 2007; 67: 609-615.

8. Dong $\mathrm{M}$, How $\mathrm{T}$, Kirkbride $\mathrm{KC}$, Gordon $\mathrm{KJ}$, Lee JD, Hempel N, Kelly P, Moeller BJ, Marks JR, Blobe GC. The type III TGF-beta receptor suppresses breast cancer progression. J Clin Invest 2007; 117: 206-217.
9. Esslimani-Sahla M, Thezenas S, SimonyLafontaine J, Kramar A, Lavaill R, Chalbos D, Rochefort $\mathrm{H}$. Increased expression of fatty acid synthase and progesterone receptor in early steps of human mammary carcinogenesis. Int $J$ Cancer 2007; 120: 224-229.

10. Faivre EJ, Lange CA. Progesterone receptors upregulate Wnt-1 to induce epidermal growth factor receptor transactivation and c-Src-dependent sustained activation of Erk1/2 mitogen-activated protein kinase in breast cancer cells. Mol Cell Biol 2007; 27: 466-480.

11. Gestl SA, Leonard TL, Biddle JL, Debies MT, Gunther EJ. Dormant Wnt-initiated mammary cancer can participate in reconstituting functional mammary glands. Mol Cell Biol 2007; 27: 195-207.

12. Iliopoulos D, Fabbri M, Druck T, Qin HYR, Han SY, Huebner K. Inhibition of breast cancer cell growth in vitro and in vivo: effect of restoration of Wwox expression. Clin Cancer Res 2007; 13: 268-274.

13. Julien SG, Dube N, Read M, Penney J, Paquet M, Han Y, Kennedy BP, Muller WJ, Tremblay ML. Protein tyrosine phosphatase 1B deficiency or inhibition delays ErbB2-induced mammary tumorigenesis and protects from lung metastasis. Nat Genet 2007; 39: 338-346.

14. Korah R, Das K, Lindy ME, Hameed M, Wieder R. Coordinate loss of fibroblast growth factor 2 and laminin 5 expression during neoplastic progression of mammary duct epithelium. Hum Pathol 2007; 38: 154-160.

15. Kotsopoulos J, Chen Z, Vallis KA, Poll A, Ainsworth P, Narod SA. DNA repair capacity as a possible biomarker of breast cancer risk in female BRCA1 mutation carriers. Br J Cancer 2007; 96: 118-125.

16. Labbe $E$, Lock L, Letamendia A, Gorska AE, Gryfe R, Gallinger S, Moses HL, Attisano L. Transcriptional cooperation between the transforming growth factor-beta and wnt pathways in mammary and intestinal tumorigenesis. Cancer Res 2007; 67: 75-84.

17. Lahmann PH, Friedenreich C, Schuit AJ, Salvini S, Allen NE, Key TJ, Khaw KT, Bingham S, Peeters $\mathrm{PHM}$, Monninkhof E, Bueno-De-Mesquita HB, 
Wirfaelt E, Manjer J, Gonzales CA, Ardanaz E, Amiano P, Quiros JR, Navarro C, Martinez C, Berrino F, Palli D, Tumino R, Panico S, Vineis P, Trichopoulou A, Bamia C, Trichopoulos D, Boeing H, Schulz M, Linseisen J, Chang-Claude J, Chapelon FC, Fournier A, Boutron-Ruault MC, Tjonneland A, Johnson NF, Overvad K, Kaaks R, Riboli E. Physical activity and breast cancer risk: the European prospective investigation into cancer and nutrition. Cancer Epidemiol BiomarkPrevent 2007; 16: 36-42.

18. Lee YK, Thomas SN, Yang AJ, Ann DK. Doxorubicin down-regulates Kruppel-associated box domain-associated protein 1 sumoylation that relieves its transcription repression on p21(WAF1/CIP1) in breast cancer MCF-7 cells. J Biol Chem 2007; 282: 1595-1606.

19. Lei HX, Hemminki K, Johansson R, Enquist K, Henriksson R, Lenner P, Forsti A. Single nucleotide polymorphisms in the DMBT1 promoter and the progression of breast cancer. Int $J$ Cancer 2007; 120: 447-449.

20. Letessier A, Garrido-Urbani S, Ginestier C, Fournier G, Esterni B, Monville F, Adelaide J, Geneix J, Xerri L, Dubreuil P, Viens P, CharafeJauffret E, Jacquemier J, Birnbaum D, Lopez M, Chaffanet M. Correlated break at PARK2/FRA6E and loss of AF-6/Afadin protein expression are associated with poor outcome in breast cancer. Oncogene 2007; 26: 298-307.

21. Li H, Cherukuri P, Li N, Cowling V, Spinella M, Cole M, Godwin AK, Wells W, DiRenzo J. Nestin is expressed in the basal/myoepithelial layer of the mammary gland and is a selective marker of basal epithelial breast tumors. Cancer Res 2007; 67: 501-510.

22. Maroulakou IG, Oemler W, Naber SP, Tsichlis PN. Akt1 ablation inhibits, whereas Akt2 ablation accelerates, the development of mammary adenocarcinomas in mouse mammary tumor virus (MMTV)-ErbB2/Neu and MMTV-polyoma middle T transgenic mice. Cancer Res 2007; 67: 167-177.

23. Park BK, Zhang HL, Zeng QH, Dai JL, Keller ET, Giordano T, Gu KN, Shah V, Pei L, Zarbo RJ, McCauley L, Shi ST, Chen SQ, Wang CY. NFkappa B in breast cancer cells promotes osteolytic bone metastasis by inducing osteoclastogenesis via GM-CSF. Nat Med 2007; 13: 62-69.

24. Pervin S, Singh R, Hernandez E, Wu GY, Chaudhuri G. Nitric oxide in physiologic concentrations targets the translational machinery to increase the proliferation of human breast cancer cells: involvement of mammalian target of Rapamycin/elF4E pathway. Cancer Res 2007; 67: 289-299.
25. Rakha EA, El-Sayed ME, Green AR, Lee AHS, Robertson JF, Ellis IO. Prognostic markers in triple-negative breast cancer. Cancer 2007; 109: 25-32.

26. Rojo F, Najera L, Lirola J, Jimenez J, Guzman M, Sabadell MD, Baselga J, Cajal SRY. 4E-binding protein 1 , a cell signaling hallmark in breast cancer that correlates with pathologic grade and prognosis. Clin Cancer Res 2007; 13: 81-89.

27. Savage K, Lambros MBK, Robertson D, Jones $\mathrm{RL}$, Jones C, Mackay A, James M, Hornick JL, Pereira EM, Milanezi F, Fletcher CDM, Schmitt FC, Ashworth A, Reis JS. Caveolin 1 is overexpressed and amplified in a subset of basal-like and metaplastic breast carcinomas: a morphologic, ultrastructural, immunohistochemical, and in situ hybridization analysis. Clin Cancer Res 2007; 13: 90-101.

28. Scott GK, Goga A, Bhaumik D, Berger CE, Sullivan CS, Benz CC. Coordinate suppression of ERBB2 and ERBB3 by enforced expression of micro-RNA miR-125a or miR-125b. $J$ Biol Chem 2007; 282: 1479-1486.

29. Singh VK, Zhou Y, Marsh JA, Uversky VN, Forman-Kay JD, Liu JW, Jia ZC. Synucleingamma targeting peptide inhibitor that enhances sensitivity of breast cancer cells to antimicrotubule drugs. Cancer Res 2007; 67: 626-633.

30. Sleeman KE, Kendrick H, Robertson D, Isacke CM, Ashworth A, Smalley MJ. Dissociation of estrogen receptor expression and in vivo stem cell activity in the mammary gland. $J$ Cell Biol 2007; 176: 19-26.

31. Takabatake D, Fujita T, Shien T, Kawasaki K, Taira N, Yoshitomi S, Takahashi H, Ishibe Y, Ogasawara Y, Doihara $\mathrm{H}$. Tumor inhibitory effect of gefitinib (ZD1839, Iressa) and taxane combination therapy in EGFR-overexpressing breast cancer cell lines (MCMADR, MDA-MB-231). Int $J$ Cancer 2007; 120: 181-188.

32. Tang SS, Zhang Z, Tan SL, Tang MHE, Kumar AP, Ramadoss SK, Bajic VB. KBERG: Knowledge Base for Estrogen Responsive Genes. Nucleic Acids Res 2007; 35: D732-D736.

33. Vachon CM, Brandt KR, Ghosh K, Scott CG, Maloney SD, Carston MJ, Pankratz VS, Sellers TA. Marnmographic breast density as a general marker of breast cancer risk. Cancer Epidemiol BiomarkPrevent 2007; 16: 43-49.

34. Vegran F, Boidot R, Oudin C, Defrain C, Rebucci M, Lizard-Nacol S. Association of p53 gene alterations with the expression of antiapoptotic survivin splice variants in breast cancer. Oncogene 2007; 26: 290-297.

35. Wang Y, He QY, Chen HM, Chiu JF. Synergistic effects of retinoic acid and tamoxifen on human 
breast cancer cells: proteomic characterization. Exp Cell Res 2007; 313: 357-368.

36. Weischer M, Bojesen SE, Tybjaerg-Hansen A, Axelsson CK, Nordestgaard BG. Increased risk of breast cancer associated with CHEK2*1100delC. $J$ Clin Oncol 2007; 25: 57-63.

37. Wolff AC, Hammond MEH, Schwartz JN, Hagerty KL, Allred DC, Cote RJ, Dowsett M, Fitzgibbons PL, Hanna WM, Langer A, McShane LM, Paik S, Pegram MD, Perez EA, Press MF, Rhodes A, Sturgeon C, Taube SE, Tubbs R, Vance GH, de Vijver MV, Wheeler TM, Hayes DF. American Society of Clinical Oncology/College of American Pathologists guideline recommendations for human epidermal growth factor receptor 2 testing in breast cancer. J Clin Oncol 2007; 25: 118-145.

38. Wood CE, Register TC, Lees CJ, Chen HY, Kimrey S, Cline JM. Effects of estradiol with micronized progesterone or medroxyprogesterone acetate on risk markers for breast cancer in postmenopausal monkeys. Breast Cancer Res Treat 2007; 101: 125-134.

39. Woodward WA, Chen MS, Behbod F, Alfaro MP, Buchholz TA, Rosen JM. WNT/ $\beta$-catenin mediates radiation resistance of mouse mammary progenitor cells. Proc Natl Acad Sci USA 2007; 104: 618-623.

40. Yao ES, Zhang H, Chen YY, Lee B, Chew K, Moore D, Park C. Increased beta(1) integrin is associated with decreased survival in invasive breast cancer. Cancer Res 2007; 67: 659-664.

41. Zhang H, Pelzer AM, Kiang DT, Yee D. Downregulation of type I insulin-like growth factor receptor increases sensitivity of breast cancer cells to insulin. Cancer Res 2007; 67: 391-397.

42. Zhang JP, Warren MA, Shoemaker SF, Ip MM. NF kappa B1/p50 is not required for tumor necrosis factor-stimulated growth of primary mammary epithelial cells: implications for NF kappa B2/p52 and RelB. Endocrinology 2007; 148: 268-278.

43. Zhu QW, Krakowski AR, Dunham EE, Wang L, Bandyopadhyay A, Berdeaux R, Martin GS, Sun LZ, Luo KX. Dual role of SnoN in mammalian tumorigenesis. Mol Cell Biol 2007; 27: 324-339.

Prepared by

R. Sutherland, J. Scorer Cancer Research Program Garvan Institute of Medical Research Darlinghurst, NSW, Australia 